\title{
Using spectral mixture analysis of hyperspectral remote sensing data to map lithology of the Sarfartoq carbonatite complex, southern West Greenland
}

\author{
Enton Bedini and Tapani Tukiainen
}

Remote sensing is the science of acquiring, processing, and interpreting images and related data acquired from aircraft and satellites that record the interaction between matter and electromagnetic energy (Sabins 1997). The 450-2500 nm wavelength region provides mineralogical information based on analysis of electronic absorption features in transitional metals, especially iron, and of molecular absorption features in carbonate, hydrate and hydroxide minerals (Hunt 1977). Landsat Thematic Mapper satellite images are widely used to interpret structure and geology, but due to their broad spectral bandpasses Landsat images cannot identify specific minerals. However, such details can be achieved by processing and analysing data from hyperspectral sensors. These sensors provide a unique combination of high spatial resolution and high spectral resolution imagery of the Earth's surface unavailable from other sources (Goetz et al. 1985).

An extensive and complex suite of alkaline igneous rocks of carbonatitic and kimberlitic affinity occurs in the base-

Fig. 1. A: Geographical and geological position of the Sarfartoq carbonatite complex in southern West Greenland (modified from Allaart 1982). B: Geological map of the Sarfartoq carbonatite complex (modified from Secher 1986). The rectangle indicates the spatial extent of the hyperspectral data analysed in this study. C: Band $6(510 \mathrm{~nm})$ of the hyperspectral image. D: Photograph of the outcropping core zone of the Sarfartoq carbonatite within the study area seen from the south-southwest. Height of slope is c. $400 \mathrm{~m}$.
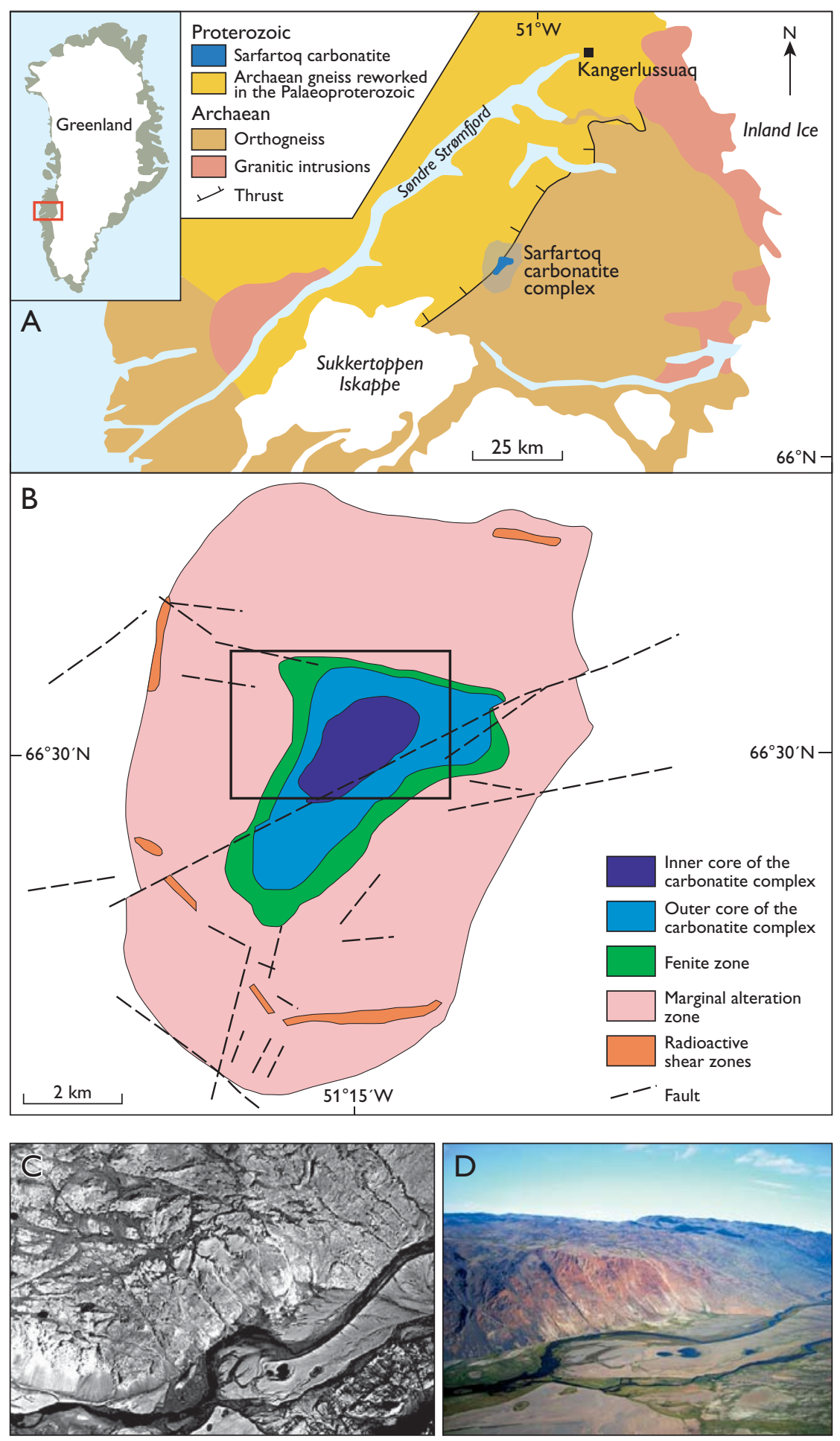


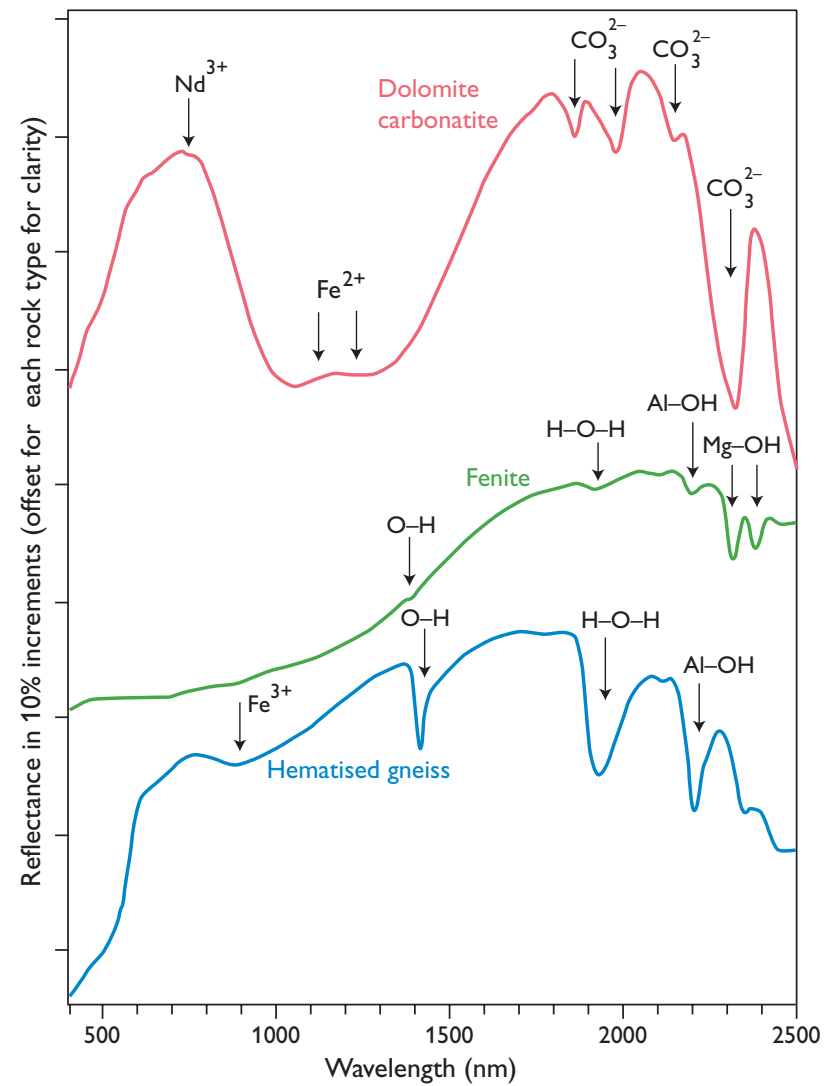

Fig. 2. Characteristic reflectance spectra of dolomite carbonatite, fenite and hematised gneiss.

ment of southern West Greenland (Larsen et al. 1983). One of the most important and major carbonatite intrusions is the Sarfartoq carbonatite complex (Fig. 1). This complex consists of an inner and an outer carbonatite core zone, a fenite zone and a marginal alteration zone (Secher \& Larsen 1980; Secher 1986). The objective of an on-going research project of the Geological Survey of Denmark and Greenland is to evaluate the use of spectral reflectance techniques and hyperspectral remote sensing data for lithologic mapping and mineral exploration of carbonatites over a known occurrence before applying it to unknown terrains. This short communication reports on the mapping results of spectral mixture analysis of HyMap ${ }^{\circledR}$ airborne hyperspectral data covering an important central part of the Sarfartoq carbonatite complex (Fig. 1). A fuller discussion is presented in Bedini (2009).

\section{Spectral reflectance properties}

Reflectance spectra were acquired using an Analytical Spectral Device (ASD Inc., USA) field-portable spectrometer, which records 2151 channels within the 350-2500 nm wavelength range. The reflectance spectra of dolomite carbonatites from the Sarfartoq carbonatite display characteris- tic carbonate absorption features with the main $\mathrm{CO}_{3}{ }^{2-}$ absorption feature centred around $2320 \mathrm{~nm}$ and exhibit a broad ferrous iron absorption feature in the 1000-1300 nm wavelength region (Fig. 2). The depth of this broad ferrous absorption feature is positively correlated with the $\mathrm{Fe}^{2+}$ content of the dolomite (Gaffey 1986). However, in reflectance spectra of ferroan carbonatites with limonitic coating, the broad ferrous absorption feature is diminished due to overlapping spectral reflectance features of ferric iron in limonite. Reflectance spectra of carbonatite rocks often display narrow, sharp absorption features at $580 \mathrm{~nm}, 740 \mathrm{~nm}, 800 \mathrm{~nm}$ and $870 \mathrm{~nm}$, which are attributed to electronic transitions in $\mathrm{Nd}^{3+}$ characteristic of rare-earth element-bearing minerals (e.g. Rowan et al. 1986).

An almost universal characteristic of carbonatite complexes is the presence of a distinctive metasomatic aureole in which the wall rocks have been converted to aegirine-rich and alkali amphibole-rich rocks (Secher \& Larsen 1980). These metasomatic rocks are commonly called fenites and the process fenitisation. Reflectance spectra of the fenitic rocks analysed here display an $\mathrm{Mg}-\mathrm{OH}$ doublet absorption feature attributed to the alkali amphibole phase present in fenite. In some cases this is associated with a shallow $\mathrm{Al}-\mathrm{OH}$ absorption feature at around $2200 \mathrm{~nm}$, due to sericite (Fig. 2).

The marginal alteration zone is distinguished by the hematisation/limonitisation of the country rocks. Reflectance spectra of samples from the marginal alteration zone display intense ferric iron spectral features in the visible and near infrared (VNIR) wavelength region (Fig. 2; hematised gneiss). This reflectance spectrum in the short-wave infrared wavelength region exhibits an intense $\mathrm{Al}-\mathrm{OH}$ absorption feature at $2200 \mathrm{~nm}$ associated with two less intense $\mathrm{Al}-\mathrm{OH}$ absorption features at 2350 and $2450 \mathrm{~nm}$, typical for sericite (Fig. 2).

\section{Sarfartoq HyMap data}

The HyMap is an airborne imaging system developed by Integrated Spectronics, Australia, and operated by HyVista Corporation. It consists of sensors located on a fixed-wing aircraft typically flown at an altitude of $2.5 \mathrm{~km}$. The sensors collect reflected solar radiation in 126 bands covering the 450-2500 $\mathrm{nm}$ wavelength range, including the visible to near-infrared (VNIR) and short-wave infrared regions of the electromagnetic spectrum (Cocks et al. 1998). The Sarfartoq HyMap scenes are part of the HyperGreen-2002 project of the Geological Survey of Denmark and Greenland (Tukiainen \& Thorning 2005). They were recorded on 9 August 2002 with $4 \mathrm{~m}$ nominal pixel size. The HyMap data were atmospherically corrected using the ATCOR4 model (Richter $\&$ Schläpfer 2002). 

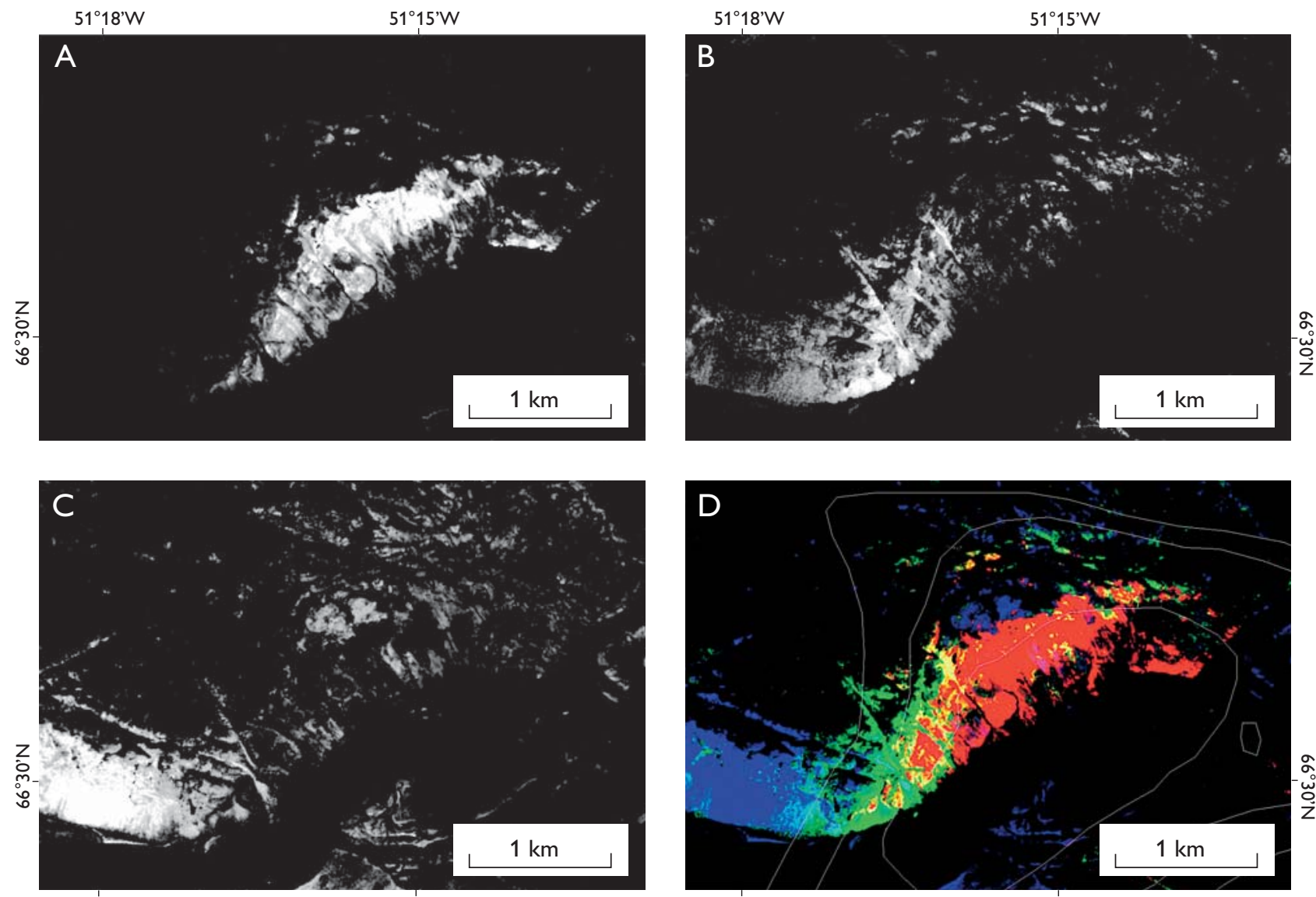

$51^{\circ} 18^{\prime} \mathrm{W}$

$51^{\circ} 15^{\prime} \mathrm{W}$

$51^{\circ} 18^{\prime} \mathrm{W}$

$51^{\circ} 15^{\prime} \mathrm{W}$

Fig. 3. Fraction abundances produced from the spectral mixture analysis for $\mathbf{A}$ : Carbonatite. B: Fenite. C: Hematised gneiss. D: Colour composite of the fractions for carbonatite $=$ red, fenite $=$ green and hematised gneiss $=$ blue. Yellow is a mixture of fenite and carbonatite.

\section{Data analysis and results}

Dark pixels (using a threshold of 5\% mean reflectance) and green vegetation (using a threshold based on the normalised difference vegetation index, NDVI) were filtered out. The hyperspectral data were mean normalised (i.e. each spectrum was divided by its mean). This form of normalisation eliminates effects of different albedo in the spectral unmixing results (e.g. Berman et al. 2004). The minimum noise fraction (MNF) transformation (Green et al. 1988) was applied to the normalised data. The MNF is a form of principal components analysis but instead of ordering the data in terms of variance, the data are ordered based on the signal-to-noise ratio. In our case the first $20 \mathrm{MNF}$ bands contained most of the information. Image-derived spectral endmembers representing carbonatite, fenite and hematised gneiss were used as input to the spectral mixture analysis (Settle \& Drake 1993), which was applied in the MNF space. The application of the spectral mixture analysis in a subset of MNF bands is advantageous, as noise isolated in the excluded MNF bands does not influence the spectral unmixing (e.g. Nielsen 2001). The sum of the fractions was not constrained. The fractions pro- duced from the spectral unmixing analysis were filtered using a $3 \times 3$ median filter. The spectral unmixing results for the three targets of interest, carbonatite, fenite, and hematised gneiss are shown in Fig. 3A-C. A colour composite of the fractions is shown in Fig. 3D.

The unmixing analysis produced good results for the carbonatite class. The fenite zone and the marginal alteration zone are well mapped within the exposed part of the carbonatite complex along the valley. An important result of the spectral unmixing analysis is the mapping of the outer core zone of the carbonatite consisting of fenitised country rock and carbonatite dykes, distinguished by image analysis as a mixture of fenite and carbonatite (yellow in the colour composite). Other parts of the scene are spectrally dominated by the vegetation cover (grass and lichen), although a mixture of gneiss and lichen is also detectable in some parts of the area. Field validation of the remote sensing mapping results showed accurate mapping of the carbonatite outcrop. The fenite class shows some confusion with the country rocks. Numerous altered spots representing the marginal alteration zone have been detected on the plateau. However, it should 
be mentioned that the vegetation cover (lichen and grass) reduces its detection. In the Arctic environment of southern West Greenland green tundra vegetation and lichen constitute a major challenge for remote sensing applied to map surface mineralogy and lithology (e.g. Rivard \& Arvidson 1992).

\section{Concluding remarks}

Spectral mixture analysis of HyMap hyperspectral data was used to map the outcropping rock types (carbonatite, fenite, hematised country rock) of the Sarfartoq carbonatite complex. The spectral unmixing produced good results for the carbonatite class, distinguishing the inner and outer core zones (the latter as a mixture of fenite and carbonatite) of the carbonatite complex within the study area. To our knowledge, this is the first study that reports the mapping of fenites using hyperspectral reflectance data. In a hyperspectral remote sensing study by Rowan et al. (1995) of the Iron Hill carbonatite-alkalic igneous rock complex, Colorado, USA, using data from the airborne visible/infrared imaging spectrometer (AVIRIS), fenite could not be distinguished due to low degree of rock outcrop and lower spatial resolution of the hyperspectral data.

Analysis of high spatial and spectral resolution remote sensing data provides spatially contiguous mineralogical and lithological information for outcropping carbonatite complexes. In inaccessible areas it cannot easily be obtained in any other way. Such information is valuable in multi-disciplinary geological studies of carbonatites and, if combined with other types of data obtained by geophysical, geochemical and petrological techniques, it can assist in mapping and mineral exploration of carbonatite complexes. With future high quality hyperspectral data acquired from sensors mounted on satellites (Staenz 2009), the availability and areal coverage of such datasets will increase, opening new possibilities for the use of hyperspectral remote sensing in geology.

\section{References}

Allaart J.H. 1982: Geological map of Greenland 1:500 000. Sheet 2 Frederikshåb Isblink - Søndre Strømfjord. Copenhagen: Geological Survey of Greenland.

Bedini, E. 2009: Mapping lithology of the Sarfartoq carbonatite complex, southern West Greenland, using HyMap imaging spectrometer data. Remote Sensing of Environment 113, 1208-1219.

Berman, M., Kiiveri, H., Lagerstrom, R., Ernst, A., Dunne, R. \& Huntington J. 2004: ICE: a statistical approach to identifying endmembers in hyperspectral images. IEEE Transactions on Geoscience and Remote Sensing 42, 2085-2095.
Cocks, T., Jenssen, R., Stewart, A., Wilson, I. \& Shields, T. 1998: The HyMap airborne hyperspectral sensor: the system, calibration and performance. In: Schaepman, M., Schläpfer, D. \& Itten, K.I. (eds): Proceedings 1st EARSeL workshop on imaging spectroscopy, Zürich, 6-8 October, 1998, 37-43. Paris: EARSeL.

Gaffey, S. J. 1986: Spectral reflectance of carbonate minerals in the visible and near infrared (0.35-2.55 microns): calcite, aragonite, and dolomite. American Mineralogist 71, 151-162.

Goetz, A.F.H., Vane, G., Solomon, J.E \& Rock, B.N. 1985: Imaging spectrometry for Earth remote sensing. Science 228, 1147-1153.

Green, A.A., Berman, M., Switzer, P. \& Craig, M.D. 1988: A transformation for ordering multispectral data in terms of image quality with implications for noise removal. IEEE Transactions on Geoscience and Remote Sensing 26, 65-74.

Hunt, G.R. 1977: Spectral signatures of particulate minerals in the visible and near infrared. Geophysics 42, 501-513.

Larsen, L.M., Rex, D.C. \& Secher, K. 1983: The age of carbonatites, kimberlites and lamprophyres from southern West Greenland: recurrent alkaline magmatism during 2500 million years. Lithos 16, 215-221.

Nielsen, A.A. 2001: Spectral mixture analysis: linear and semi-parametric full and iterated partial unmixing in multi- and hyperspectral image data. International Journal of Computer Vision 42, 17-37.

Richter, R. \& Schläpfer, D. 2002: Geo-atmospheric processing of airborne imaging spectrometry data. Part 2: atmospheric/topographic correction. International Journal of Remote Sensing 23, 2631-2649.

Rivard, B. \& Arvidson, R.E. 1992: Utility of imaging spectrometry for lithologic mapping in Greenland. Photogrammetric Engineering \& Remote Sensing 58, 945-949.

Rowan, L., Kingston, M.J. \& Crowley, J.K. 1986: Spectral reflectance of carbonatites and related alkalic igneous rocks: selected samples from four North American localities. Economic Geology 81, 857-871.

Rowan, L.C., Bowers, T.L., Crowley, J.K., Anton-Pacheco, C., Gumiel, P. \& Kingston, M.J. 1995: Analysis of airborne visible-infrared imaging spectrometer (AVIRIS) data of the Iron Hill, Colorado, carbonatitealkalic igneous complex. Economic Geology 90, 1966-1982.

Sabins, F.F. 1997: Remote sensing: principles and interpretation, $432 \mathrm{pp}$. New York: W.H. Freeman and Company.

Secher, K. 1986: Exploration of the Sarfartôq carbonatite complex, southern West Greenland. In: Kalsbeek, F. \& Watt, W.S. (eds): Developments in Greenland geology. Rapport Grønlands Geologiske Undersøgelse 128, 89-101.

Secher, K. \& Larsen, L.M. 1980: Geology and mineralogy of Sarfartôq carbonatite complex, southern West Greenland. Lithos 13, 199-212.

Settle, J.J. \& Drake, N.A. 1993: Linear mixing and the estimation of ground cover proportions. International Journal of Remote Sensing 14, 1159-1177.

Staenz, K. 2009: Terrestrial imaging spectroscopy - some future perspectives. 6th EARSeL SIG IS Workshop, Tel Aviv, Israel, 16-18 March, 2009.

Tukiainen, T. \& Thorning, L. 2005: Detection of kimberlitic rocks in West Greenland using airborne hyperspectral data: the HyperGreen 2002 project. Geological Survey of Denmark and Greenland Bulletin 7, 69-72.

\footnotetext{
Authors' address

Geological Survey of Denmark and Greenland, Øster Voldgade 10, DK-1350 Copenhagen K, Denmark. E-mail: ebe@geus.dk
} 